\title{
URBAN DEVELOPMENT IN OMAN: AN OVERVIEW
}

\author{
NAIMA BENKARI \\ Department of Civil and Architectural Engineering, Sultan Qaboos University, Oman
}

\begin{abstract}
During the past two decades, the Gulf countries have experienced the most rapid urban growth in the world. The traditional societies in this region have been guilelessly opened on the market economy and western lifestyle. In spite the progress realized at many levels, these societies became victims of its consumerist style. This article aims to present an overview of the urban development in Oman since it started its 'modernization'. This study is not only interested in how the country has been developing since its "renaissance" in the 1970s, but also how does this development appear, compared to its traits in the neighboring Gulf countries. Based on the assumption that urban research is a tool of analysis that can enlighten future decisions and actions in the domain of urban development, this study is also a critical review of the published research about the urbanization in Oman since the 1970s. This research showed that, although it shares several aspects with what the other Gulf cities have witnessed, urbanization in Oman was slower, less drastic and relatively more controlled. The scrutiny of the published research on this topic also revealed that the urban studies about Oman, and the GCC countries in general, were insignificant before the rise of leading cities such as Dubai, then Doha, to the international scene. It concluded that even if these urban studies have progressively broadened in their topics, disciplines and case studies, their effect on the new orientations chosen for the future developments in these countries remains negligible.

Keywords: Gulf countries, instant cities, mega-projects, Muscat, Nahdha, urban growth, urban research, urbanism, urbanization.
\end{abstract}

\section{INTRODUCTION}

Hasty and barely controlled, are the first ideas that come to mind when the urbanization in the Gulf cities is brought into a discussion. The GCC (Gulf Cooperation Council) countries are witnessing an unprecedented urban transformation ever since the discovery and commercialization of oil in the region in the early 1960s. Rapid urbanization was dictated by the needs of the newly formed states, but land speculation and competition for the "lead" were the most powerful instruments of this spectacular urban growth. Relatively to the importance of this phenomenon that imprinted all the GCC countries, little research has addressed the different facets of urbanization in these countries.

The present study argues the case for a more focused research and mature interpretations as important means to knowledge production in this nascent field of Gulf Urban Studies. It addresses questions related to the urban development in Oman since this country is the least investigated by the thinly published research on the subject. Urban development includes not only the physical changes in the cities (urbanization) but also their economic, social and cultural transformations and the underlying causes of these processes. By addressing such a subject in Oman, this study positions itself in the discipline of "urbanism". Based on the assumption that urban research is a tool of analysis that can enlighten future decisions and actions in the domain of urban development, this study offers also a critical review of the published research about the urbanization in Oman since the 1970s. After almost half century of urbanization and urban research in Oman, it is the right time to undertake such reviews in order to synthesize what has been done so far, identify the gaps of knowledge in this field and pave the way for future research. 


\subsection{Methodology}

This research is primarily based on the study of the available literature that addressed the urban development of Oman. A classification by discipline, level of specialization language and even on the sources used in such research (primary, first-hand oral or written source, field research, observations, etc.) has facilitated the articulation of the article's content. The many years spent by the author in Oman observing its slow, yet uninterrupted transformation, and the several discussions with a wide array of actors in the built environment have also enriched the content of this study and its conclusions. The substance of this research findings are presented in the main sections of this article: section two discusses the urban development in Oman, with a focus on the post-1970s period, also known by the renaissance: "Al-Nahdha" era. And section three is dedicated to the critical review and analysis of the scientific literature produced about the urbanization in Oman.

\section{THE PROCESS OF URBAN DEVELOPMENT IN OMAN}

Unlike most of the GCC countries, some of the actual cities of Oman have a history of several centuries. Thanks to its strategic location between the expanded coasts and the deep desert, protected by its impenetrable mountains, Oman has always played a key role in commercial roads which participated for a great deal in the flourishing of several civilizations in the region. The urban development of Oman has been deeply influenced by the different civilizations that settled in the country throughout its long history. This process started some five thousand years ago by the autochthone populations, then by the Sumerian civilization in the third millennium B.C. During this era, Oman was named Majan 'Copper Mountain'. The Persians colonized the coastal region of Majan during these times and consequently, they spread their influence on the commerce and cultural life in the region [1]. Omanis of that time established trade relationships with Africa, India, and China. This is how they became pioneers of the sea trade in the Oriental world. Arabs settled in Oman coming from Yemen in the 1st century AD. They established a town that will become the origin of Harat Al Bilad in today's Manah [2]. From the early Islamic period in Oman (since early 7th century AD.), until the Al-Nahdha or "renaissance" era, there was no formal planning shaping the settlements. Islamic principles influenced the urban growth of the Omani cities as it was the case in the rest of the Middle-east [3]. The inhabitants were directly involved in the making of their neighborhoods, therefore, towns and villages evolved harmoniously (Fig. 1).

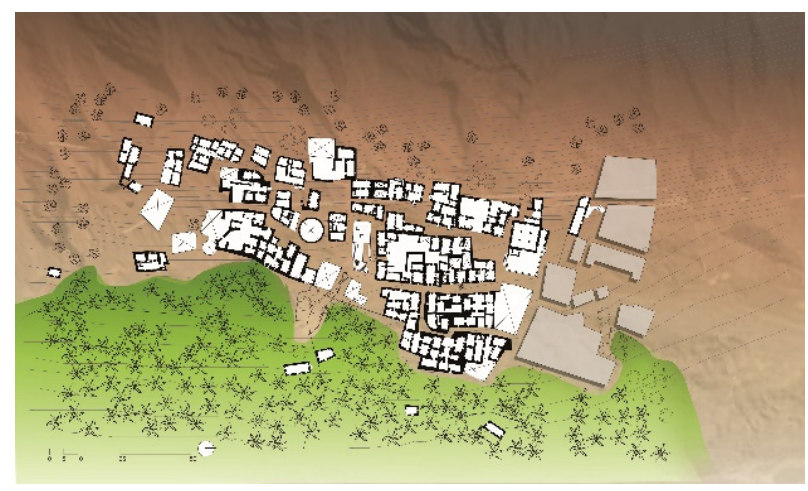

Figure 1: An example of a traditional settlement in Oman: Harat Saija in Samail. (Source: author.) 
Oman coasts withstood several incursions by the Persians, then the ottomans and subsequently by the Portuguese at the turn of the sixteenth century. The later settled along the coasts where they built several military structures. The Omanis withdrew from the coasts to protect their independence behind the mountains, where they consolidated their defensive systems, which were never crossed by the invaders. Since the liberation of the land from the Portuguese by the Al-Ya'arubi Imams, in the seventeenth century, most of the strategic cities in Oman had their defensive character consolidated [4] (Fig. 2).

In the early $18^{\text {th }}$ century, the newly elected Imam Ahmed Bin Sa'id started the Al-Bu Said dynasty, which is still ruling Oman today. The capital of the country was moved from Rustaq to Muscat. There was no significant planning in the country until the turn of the $20^{\text {th }}$ century [5]. This era witnessed an impressive expansion of the country, which reached India and East Africa where the capital of the Al-Bu Said ruler was relocated in Zanzibar. This had negatively affected the urban development in Muscat, which declined progressively. A real urban development started in the early 19th century when the Sultan returned to Muscat, then the second phase of this "revival" happened between the end of the 19th and beginning of 20th centuries (Fig. 3).

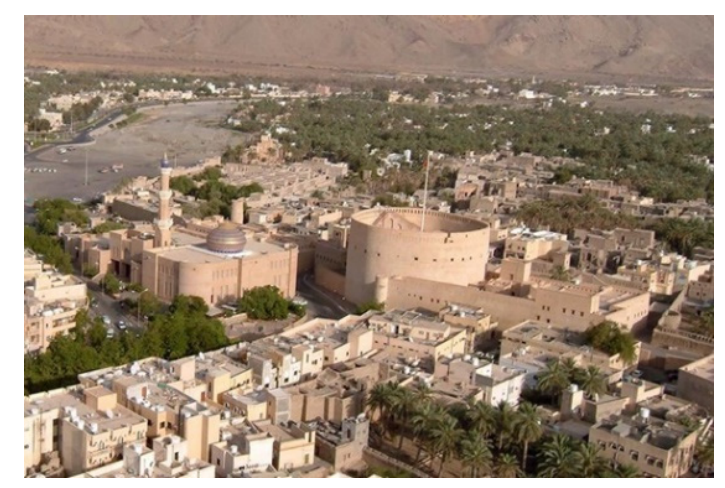

Figure 2: Nizwa fort, with the great mosque dominating the Souq of the city. (Source: http://jumboarabia.com/oman/2013/03/the-luring-cities-of-oman/)

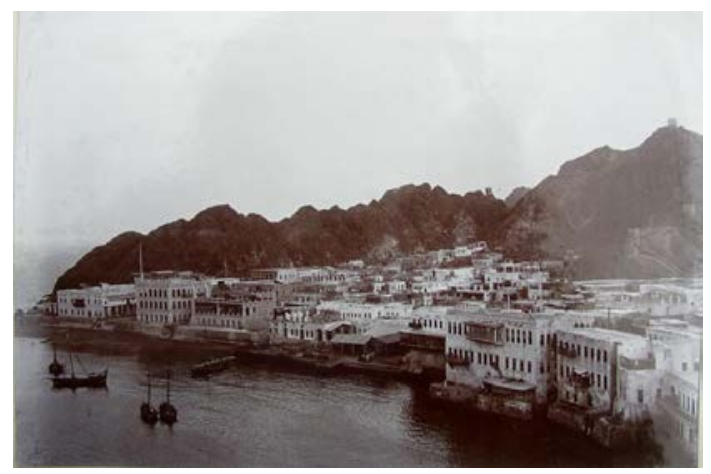

Figure 3: Old Muscat. (Source: http://www.heathcaldwell.com/hh_sultan_taimur_bin _turki_1913) 
This fragile awakening of Muscat was not to last. The withdrawal of the ruling family from Zanzibar started the end of the "Golden era" of the Empire of Muscat and Oman. The central authority weakened dramatically and cities such as Sohar, Rustaq, and even Muscat, regressed economically and their urban development stagnated. This situation will not improve until the beginning of the "renaissance" era which started in 1970, when the actual Sultan, Qaboos Bin Said Al Busaidy, became the ruler of the Sultanate of Oman.

\subsection{The urban development in Oman under the shadow of the oil boom (1970 onward)}

In order to understand the urban development in Oman since the 1970s, this article will focus on the most studied aspects of this development by researchers in this field. These aspects will be presented within the context of the Gulf countries, in order to define the uniqueness of Oman's urban development process compared to its neighbors. We argue that, while presenting a number of common traits with the urban growth in the GCC countries, the development in Oman distinguishes itself by certain aspects that make it a singular experience, worthy to investigate.

\subsubsection{Common beginnings: social transformations and "westernization" of the built environment}

During the past half century, the oil-rich Gulf countries started a period of profound and unprecedented socio-economic change. This was possible thanks to the oil windfalls that these states started harvesting as soon as the early 1960s. The combined effects of this situation have characterized the type of development in these countries. The ultimate traits of this growth were: a hasty, uncontrolled and unconditional opening on the exterior world, especially the western part of it. Ben-Hamouche [6] argues that this avid acceptance of the Western model was provoked and maybe justified by the feeling of retardedness and the aspiration to progress. This westernization was not only at the level of consumption styles but it affected also the social re-compositions and urbanization process. Since the early years of the oil boom, British and American oil companies were attracted to the Gulf region for the exploitation of this new wealth. They began building new towns for their employees working on the site. Aramco in Saudi Arabia is one of the pioneering examples of these communities. Many versions of such "western" settlements and city making, mushroomed in GCC countries, including Oman. This is how the western city planning principles were introduced to the whole region [7].

Most of the traits characterizing the urbanization during this period are common to all Gulf countries. The western principles had a significant imprint on local strategies, which subsequently formed the foundation of the planning system in these States. The right of decision-making was gradually shifted from the traditional community and tribes representatives to be conveyed to specialized ministries, executive directorates and foreign consultants [8], [9]. This is how firms like Llewellyn-Davies Weeks and Weidleplan \& Muamir have largely influenced the development strategies, and urban planning policies in Oman [10]. It is worth mentioning that a higher proportion of local population, less important oil resources and a more restrained and social oriented transformation have kept a close control on the progressive urbanization in Oman. The endogenous factors continued to imprint the spatial configuration of the built environment, even if, after more than 4 decades of "modernization" this configuration started to show symptoms of social reconfiguration especially within the urban area of the capital Muscat [11]. 


\subsubsection{Considerable rural to urban migration}

In the Gulf, the capital cities are the main cultural, economic and administrative centers in their countries. Because of their political importance, these capitals were the focus of most of the development effort deployed by the governments. Because they are meant to be the symbols of the growth and wealth of the nation, the capital cities absorb most of the construction and development budget of these countries. If this development style succeeded in propelling some of the GCC capitals among the first-class cities in the world, it has nevertheless left wide areas secluded and underdeveloped. The drastic centralization of the services, facilities and decision making in the capitals has led to their over-densification and a de-population of the small towns, traditional villages and other inhabited zones in the peripheries. Similarly, urbanization in Oman has been increasing at a fast rate. From approximately $30 \%$ in 1970 and around $50 \%$ a decade later, it grew to reach $80 \%$ today and is expected to range around $85 \%$ by 2040 (Fig. 4). The continuously increasing, migration of rural households to urban areas is the main pressure behind the fast urbanization in Oman and elsewhere in the region. This rural to urban migration is mainly caused by the wide difference in development factors (such as household income, provision of infrastructure and access to social amenities) [10].

Muscat is the largest and most congested region in Oman. Because of the abovementioned reasons, immigration to Muscat has been consistently increasing during the past forty years. This has created a growing pressure on the city and its region where $29.1 \%$ of the total population is congested in $5.3 \%$ of the total area of the country [11]. A large number of the internal immigrants (estimated at 500,000 persons) [12] would spend the weekends and holidays in their towns and villages "Al-Bilad", and commute back to the city during the working days. The reason is that this generation is the first to immigrate to Muscat, therefore strong connections still remain with the families and tribes in the towns and villages of origin [13]. There is no doubt that this increasing migration to Muscat is the main cause of several problems such as the pressure on the urban facilities, the water and electricity provisions, the congestion of roads and other urban infrastructure. It has even affected the gradual transformation of the urban settlement pattern in the city. In fact, the spatial configuration of

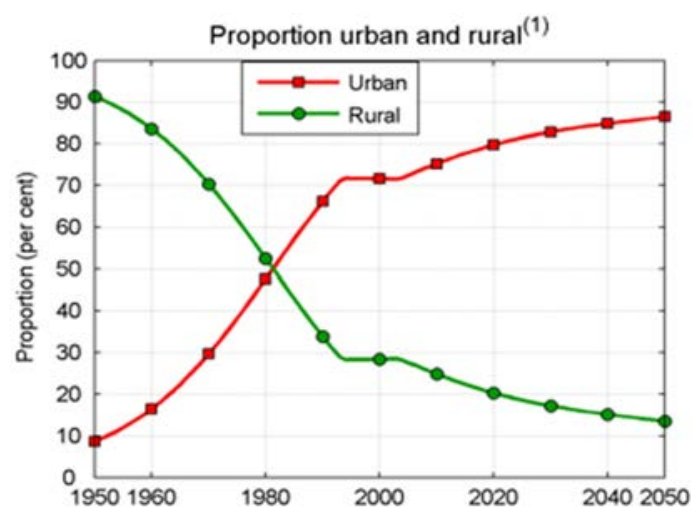

Figure 4: Proportion of urban vs. rural in Oman. (Source: United Nations, Department of Economic and Social Affairs, Population Division, 2014. World Urbanization Prospects: The 2014 Revision.) 
the urban area of Muscat started to show symptoms of social stratification reflected by what Mokhtar [11] has identified as "spatial polarizations", where families with the highest incomes settled in the most expensive areas along the coast (Al Qurum), and the new developments in their vicinities (Madinat Sultan Qaboos and Al Khuweir), while the most congested parts of the city (Ruwi) are populated by households with more modest income.

\subsubsection{Mega-projects and infrastructure-led development}

The generous oil-incomes helped the GCC countries to embark, quite early in their growth timeline, on heavy investments in widespread road and electricity networks, reaching most of the remote areas of their territories. The initially basic infrastructure designed to serve and increase oil production, have rapidly evolved into full-fledged industrial cities (Yanbu and Jubail in Kingdom of Saudi Arabia, Dubai's Jebel Ali, etc.). Similarly, the state of the Art ports, Airports, and public transportation networks were established to connect these countries to the world and facilitate traveling within their boundaries. Like its neighbors, though in a more restrained fashion, Oman invested in transportation (roads, highways, airports and ports). Two Ports (Sohar and Duqm), two international airports (Muscat and Salalah), and 6 local ones (Duqm, Adam, Sohar, Ras Al-Had, Haima, and Shaleem) are being built or started operating already. In the same way, the country invested in the construction of public buildings. Since the 1980s, this type of projects occupied the largest portion of the built-up surfaces in the country. In Muscat, it represented around $29.8 \%$ of the total built-up area in 1980, before increasing to $30.2 \%$ in 2003 [14] (Fig. 5).

Most of the GCC countries invested heavily in Mega-projects to promote a rapid economic growth. This "oil urbanization" will become a common trait in the capital cities of the Gulf. Dubai is the fastest growing city in the region (more than 112 mega-projects were planned within its boundaries) [15]. The city's growth strategies set an example for other capitals in the region. This has resulted in numerous duplications in urban strategies, trends and even speculative approaches [15]. All that the Gulf cities hope to achieve through development is to become global and even world first class cities. These cities, with Dubai at the lead, produced the most impressive and criticized examples of mega-projects: The palm and the World islands in Dubai, The Pearl in Doha, Durrat Al-Bahrain in Manama, and Tarut Island in Saudi Arabia [16]. Bagaeen [17] defines this type of development by "instant cities" or "cities within the cities". Such developments become the pivotal points of governments" actions to promote real estate products. To prepare the beyond oil transition of their economy,

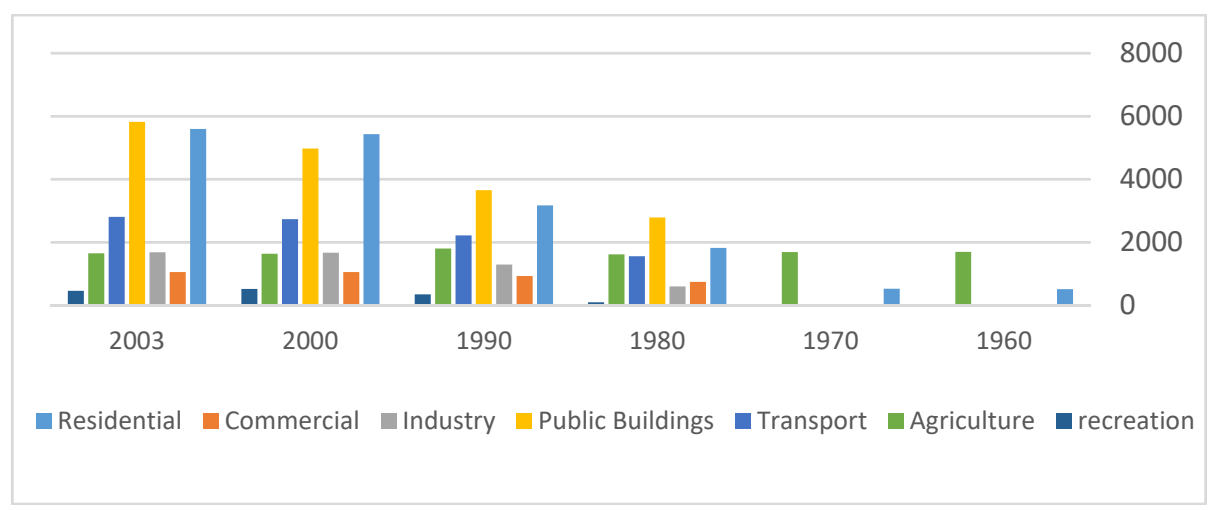

Figure 5: Total areas in hectares per land use class and per year studied. (Source: graph generated by the author based on Al-Awadhi [14].) 
the GCC countries continue to invest in mega-projects [18]. They have initiated an increasing number of service and knowledge-based developments such as Dubai Knowledge village, Education city in Doha, and knowledge oasis in Muscat.

Oman was late in joining this trend for several reasons, the country's less generous resources are but one among others. Since the beginning of its Nahdha "renaissance", Oman had a more cautious and slower but sustained progress. The planning of the growth of Muscat and, to a less extent, the rest of the country, was meticulously guided by the highest authorities, through an arsenal of regulations, laws, and amendments. It is only lately, and probably to orient the country's economy towards more diversified sources of income, that Oman joined its neighbors in planning for new Mega-developments, some of which were cofunded by Qatar or the UAE. Projects such as Al-Mooj "The Wave", Duqm, Jabal Sifah, Salalah Beach and Al Madinah A-Zarqah "blue city", are either completed or in an advanced stage of completion.

\subsubsection{A growth model based on sprawl and refills and the re-formation of the city's identities}

Since their urbanization was mainly driven by the Mega-development projects, urban sprawl, and urban refills were the development strategies shared by all GCC cities [19]. This has transformed those cities into a sort of "assemblage" of fragments, rather than complex entities operating together in harmony. This fragmentation was perceptible in the buildings' architectural styles and was also imprinting the physical experience in these cities. As if the projects were blindly thrown in the desert without physical connection or functional complementarity. Further developments would come later to fill in the gaps physically while the functional disruption and the architectural "cacophony" would just get worse. In such a vehement rush towards globalization, there was a constant negotiation between tradition and "modernity". In spite the plaidoyers about the Arab and Islamic identity in the architectural and urban proposals for the Gulf cities, this identity was hard to find on the ground. Rather, some fake images and pastiche were the common product in this "business". In many cases, large parts of the authentic traditional urban fabric were simply erased to be replaced by a brand new, western-like structures. Therefore, most of the Gulf cities have gradually lost their local identity, in spite the "aesthetic operations" made here and there through the adoption of Neo-traditional styles in the architecture of some buildings and urban spaces (Madinat Jumeirah in Dubai, Katara in Doha) (Fig. 6).

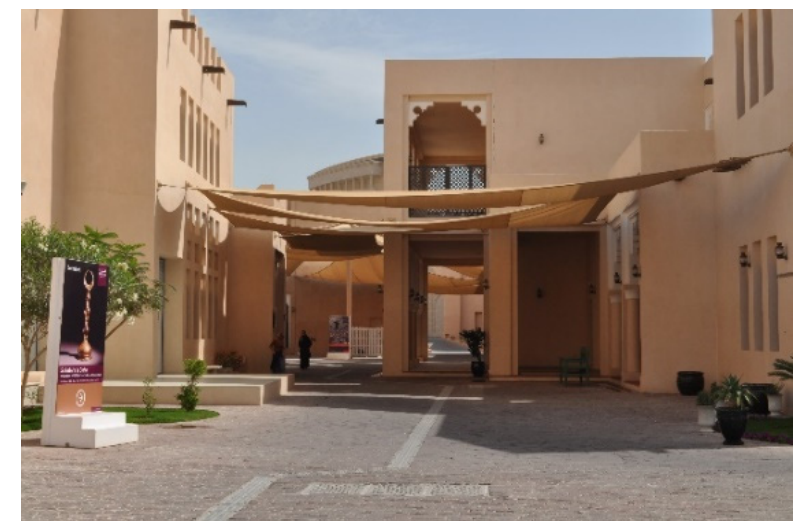

Figure 6: Open space in Katara-Doha. (Source: author.) 
Obviously, the urban transformation of Dubai presents the most prominent image of the effect of globalization on an oil-rich Arab city. This image was praised sometimes and disparaged more frequently, especially after the 2008 world financial crisis, which caused a great deal of distress to the real estate market in Dubai [20], [21]. The situation in Muscat is slightly different, thanks to the strong hold the central government has on the development of the city, and the clairvoyant regulations related to the urban interventions in the city's traditional fabric (Building Regulations issued in 1981, Ministerial Decree 40/81). With all the fairly expressed reserves against the way this law has been implemented so far, one can argue that without these regulations, this city would have completely lost its particular cityscape today.

As far as the growth pattern is concerned, it seems that Muscat is going in the same direction as the rest of the Gulf capitals. Its urban area is growing with urban sprawl and refills. This urban area is the result of the conglomeration of small historical centers which developed and grew to form the "assemblage" which makes the greater Muscat of today [11]. From the increasingly urbanized area of A-Seeb in the north to the fishing port of Quariyat in the south, the capital area stretches on $200 \mathrm{~km}$ of the coastline along the Gulf of Oman. The urban growth pattern of Muscat has been addressed by two recent studies undertaken by two geographers from Sultan Qaboos University [11], [14]. In the first study, Al-Awadhi [14] used remote sensing techniques and GIS imagery to measure the expansion of the capital's built-up area and studied the land-use development between 1960 and 2003. While in his thoroughly documented study, Mokhtar [11] explored the effect of social transformations in Muscat on the land price and physical distribution of the different social classes in the city.

Al-Awadhi [14] showed that between the period 1970 and 2003, the greater Muscat has recorded an expansion of $650 \%$ with an annual growth rate of $20 \%$ approximately (Fig. 7 ). While the decade of 1970 to 1980 has witnessed a major intensification in urban growth with more than 3.5 times the previous stage, and a sustained increase in the residential land (Fig. 5). Simultaneously, three types of urban expansion have been identified by the study of the land use in the concerned area [14]. The first type took place during the first decade of A-Nahdha, (1960-1970) where the growth was very narrow and linked the old towns of Mutrah and Muscat. The second expansion was during the second decade of A-Nahdha. It spread more than $60 \mathrm{~km}$ to the west along the coast. Finally, the urban expansion started to fill the gaps between the built-up areas, between 1980 and 2003. Based on the calculations of Al-Awadhi [14], it seems that the annual urban expansion rate in the period 1960-2003, was $17.1 \%$ with an average built-up area of 393.8 hectares. Building on these observations,

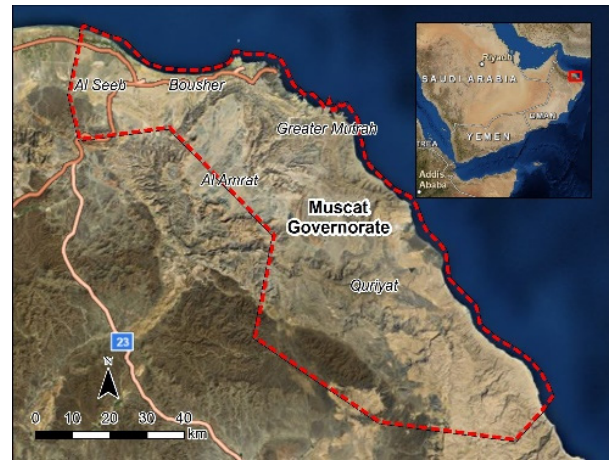

Figure 7: Map of greater Muscat. (Source: http://www.norplan-oman.com/newaddressing-system-for-muscat-governorate/) 
he estimated that the rate of urban expansion within the period 2005-2050 will be around $6.16 \%$. He predicted that the future expansions of Muscat would proceed following sequence models that would first fill the gaps between existing built-up areas, then expand along the edges of existing settlements to finally create new satellite settlements around the existing urban margins [14].

On the other hand, following the results of the research by Mokhtar [11], the social distribution of the population of Muscat seems to be evolving from a tribal or even ethnic based distribution which prevailed until the 1970s, to a sort of socio-economic polarization and stratification, based on the price of land. Schematically presented, the social distribution in the great Muscat is organized following two poles of high land prices and where the services and cultural facilities are concentrated. The first pole is the most urbanized coastal areas (Al Qurum) and their vicinities (Madinat Sultan Qaboos and Al Khoweir, hosting ministries, embassies, opera house, Sultan Qaboos Grand Mosque, and a variety shopping malls.) and the other is the service-oriented areas of Al-Khoudh, and A-Seeb (Where Sultan Qaboos University and Oasis knowledge are implanted along with other important services and commercial centers). The least costly lands are those located between these two poles.

\subsubsection{The urban expansions infringe agricultural lands and traditional settlements}

Since the very sense of development conveys a spatial change, the different socio-economical mutations in the Gulf countries negatively affected their traditional space. The increase of commercial interests in buildable lands, due to the Economic growth, and the aggressive land speculation, led by multinational developers and local investors, caused incursions and sometimes complete eradication of the traditional towns and villages in the region. Those old centers were perfectly sustainable because adapted to their climatic, geographic and economic conditions and were the physical expressions of their populations' social organizations and customs. The agricultural lands that coexisted with those old settlements were also gradually invaded by urbanization and occupied by new developments, dedicated to residential, commercial and services projects, along with their necessary infrastructure.

Even if these conditions were almost common to all the GCC countries, their spatial repercussions manifested differently in each case. In a country like Oman, where mountains and valleys are enclosing the capital area within a thin coastal strip, any flat land in this territory was good to be built. Therefore, the old urban centers and agricultural lands of Al-Batinah have dramatically shrunk under the pressure of an urban sprawl facilitated by the improvement in transportation infrastructure in this region [22], [23]. With the exception of relatively rare studies [24]-[26], research is very limited about the effect of urbanization on the traditional towns and villages in Oman.

\subsubsection{No consideration for the environment: unsustainable urbanization}

Based on a United Nations' report, 75\% of global resources are consumed by cities which produce an even larger proportion of global waste, while they cover only $2 \%$ of the total area of land in the world [27]. The American urbanization model, applied by GCC countries in their cities, is indeed among the main causes of the 'three global highs' in the world (high oil and food prices, high gas emissions) [27]. Over the past half century, the competition for "socio-economic development" between the GCC countries has principally focused on mega-urban projects built on reclaimed lands. Researchers are investigating the disturbance caused, by the development of urban infrastructure in these countries, to the natural environment, especially the coastal regions, mangrove ecosystem [18], [28] and wadis' flow frequencies [29]. Even if these studies are still sporadic in the blossoming research about the urban development in the Gulf, their results are converging towards the same conclusions: 
this frenetic urbanization and avid consumption of natural resources make this model of urbanization an unsustainable option for the future of humanity.

At the dawn of the third millennium, when the "sustainability" ethos was booming, the then leading Gulf countries in the field of urban development (mainly the UAE and Qatar) launched initiatives and adopted new policies and regulations towards a more sustainable and environmentally friendly development. The UAE initiated its Istidama plan with its pearl rating system; Abu Dhabi launched the first zero carbon emission city (Masdar City) [29], while Qatar originated its Sustainability Assessment System "QASAS". Unfortunately, the gap between political declarations and real implementation of the laws on the ground is still a real obstacle in the Gulf. With their urban mega-developments and western-inspired architecture improper for an arid climate, the cities in this region remain among the most polluting in the world. Oman is not much different in this matter, even if the concern about sustainability in the planning system of this country was declared much earlier than its neighbors (Law on Prevention of Pollution and conservation of the Environment. Royal Decree 10/82 modified by 114/2001). Energy and water consumptions are at their highest in this country (water consumption per capita rose by 120\% in Muscat between 2006 and 2009, and so are the levels of waste production) [30].

\subsubsection{Robust planning systems hampered by weak implementation tools}

Research about the planning policies, systems, and tools in Oman is scarce and fragmented. From the literature studied, it appeared that, contrary to what was suggested by previous researchers and by the situation on the ground, the authorities in charge of the urban planning in Oman (Ministry of Housing, Supreme Committee for Town Planning (SCTP) and municipalities) have always had strong planning strategies throughout the past five decades [10]. In fact, these formal planning regulations and procedures were introduced at the beginning of the "renaissance" era [10], in the 1970s. However, the lack of coordination between these authorities and the absence of real implementation tools, have led most of these plans to the waste. In this fast-growing environment, decision-making has become a more emergency-based process, activated by the problem's nature and urgency, rather than founded on an ideological process, where the optimum possibilities are considered and translated into practical road maps. Even today, the situation has not changed much. The key planning authorities are not coordinating their efforts at the different levels (national, regional, local, private consultants). The multitude of well-thought-out and thoroughly documented plans and proposals are lost in the implementation process due to the heavy bureaucracy that characterizes a centralized administrative system such as the one prevailing in Oman. Thus, the urban growth in the country is hectic, unbalanced and irrationally more focused on the capital and the thin coastal region of Al-Batinah.

\section{STATE OF THE RESEARCH ABOUT URBANIZATION IN OMAN}

Scientific research and field-based studies about Urbanization in the Gulf region are still quite scarce. Before the turn of the third millennium, little research has addressed the urban development of the Gulf cities and even less has been dedicated to Oman. It is Dubai then Doha's promotion on the global map, which triggered in the early 2000s, the blossoming Gulf Studies with problematics related to their urban development and social transformation. Unfortunately, though, it is not rare to find among this still limited production, some poor and commercially motivated material presented as academic work. Besides the sustained focus on the physical and economic development of the "iconic cities" in the region, research interests have gradually expanded to include a relatively larger array of cities, countries and also subjects investigated and academic disciplines involved. These new studies address questions related to the sustainability of the mega-urban developments and their effect on the 
natural environment [28], [31], [32], the After-oil strategies and development of tourism [33] the socio-economic transformations and their effect on land price [11], polarization of social classes in the city [34], or even the effect of shopping malls on the transformation of the traditional retail [12].

The first investigations on modern Oman started in the 1970s. The country was then going through its "modernization" thanks to the subsidies collected from the booming oil commercialization, and the beginning of a new era in its millenary history: A-Nahdha. These first studies were produced mainly by American and British officers and expert consultants serving the local authorities and the oil companies. These studies had a rather gratifying tone about a reborn oil-rich country in the post-1970, instead of offering objective analyses of the on-going development process [35]. Since the early 1980s, French and German researchers led the progress of modern Oman studies. With specialties in social geography and anthropology, their research interest covered, among other topics, general geographical studies, urban development and socio-spatial transformations [22], [36]. After this first movement, Oman was mainly overlooked in the research about the Gulf. It is only in the turn of the new millennium that more critical studies from a broader range of disciplines started investigating the urbanization and other topics related to the development of the country. As the first product of this regenerated research in Oman, the book edited by Lavergne and Dumortier [37] has addressed with a multi-disciplinary approach the different aspects of the country's development. The published research increased, over the past decade, the scope of subjects and the variety of disciplines have broadened considerably. The following sections will highlight the main traits of this new phase in the research about the urban development in Oman.

\subsection{The rise of local research about urban development}

Local studies addressing the several aspects of urbanization and development of cities in the Gulf are almost insignificant, compared to the urban upheaval that the region is witnessing since the past five decades. The case of Oman is not much different in this matter. Nonetheless, with the maturity of universities in this country and the development of its research funding system, there are some signs of development in this field and the studies undertaken within these universities are on the rise. The topics covered by this research include growth monitoring and modeling [14], the environmental sustainability of urban development [29], the reconfiguration process of territories [34], the socio-spatial transformations and land prices [11], or the effect of new shopping spaces on traditional retail [12]. Other research projects are still in progress, mainly in the universities of Sultan Qaboos and the German University of Technology. Their very first results have just been published and therefore could not be included in the present research. Thanks to the grants system established by the Omani government, graduates and junior administrators in different ministries and directorates, have the opportunity to pursue their Postgraduate studies abroad (Mainly in the UK and the USA). There were lately some very well documented scientific studies, made by such professionals, and which addressed different topics related to the urbanization and planning system in Oman [10], [13]. Such production is certainly essential for the formation and the consolidation of a rich and dynamic urban research in the country.

\subsection{The concentration of research on the capital city and its region}

The capital city (of the country or of the region) appears as "The" case study repeatedly investigated by the majority of the research focusing on the urban development in Oman. This choice is understandable because the capital attracts most of the effort of development, 
the highest concentration of population and most of the research interests in this field will be in the capital. Moreover, the research in the capital and its peripheries is practically easier to manage in extremely centralized administrations such as the one prevailing in Oman. The access to the research site and the availability of the needed documentation, be it in the administrations, ministries or universities, is almost a "luxury" that researchers cannot find in remote areas. It is hoped that with the multiplication of colleges and universities and administrative antennas in the different regions of the country, there will be some decentralization in this field and this will undoubtedly diversify and decentralize geographically the research topics in this field.

\subsection{Disconnection between research, planning and decision making: the missing link}

Planners and decision-makers in the different authorities regulating Oman's urban development are oblivious to the results of the research about the country's urbanization. Consequently, the results of these academic studies are not informing the decision making or the planning process. Even the research funded by the same authorities are hardly looked at during the process of planning or implementation of the plans on the ground. Similarly, when it comes to elaborate a properly documented research about topics related to urban development and city planning, the availability of documents and other sources of information is always a major challenge for the researchers. A stronger connection between research (whether is it field based or theoretical) and the city planning efforts, will certainly consolidate the importance of research for the Urban planning systems and strategies in Oman.

\section{CONCLUSION}

The present study addressed the urban development process in Oman and its challenges, within the context of the Gulf countries. It has shown that important socio-economic mutations have affected, though with less intensity than in the other States, the natural, rural and urban environments in the country. In spite the declared intentions of preserving the identity of the Omani built environment and its sustainability, the traditionally measured city making process, governed by endogen principles, has been steadily shifted to an urbanization imprinted by Western concepts completely oblivious to the local environment, the urban history and the built heritage of this country.

The scrutiny of the published research about the urbanization in Oman revealed that, although it shares several aspects with what the other Gulf countries have experienced, the urbanization in Oman was slower, less drastic and more controlled. The literature studied showed that urban research about Oman, and the GCC countries in general, was insignificant before the rise of the leading cities of Dubai then Doha to the status of global cities. Since the early 2000s, this research has been growing broader in its topics, disciplines and case studies. Nonetheless, its effect remains inconsequential on the new orientations of the future developments in Oman. Furthermore, even if urban research in this country has been growing since the last decade, important topics and more cities and regions have yet to be covered. Subjects such as urban expansion over the traditional villages, sustainability, social inclusion, Identities or urban mobility, need to find their place in the research about the urbanization in Oman. Future investigations should examine the capability of all concerned actors in the urban development, to produce collectively contemporary planning systems that promote adequate urban environments, which are neither the pale copies of the traditional cities nor the blind imitations of images from the West, but an optimum response to the aspirations of the contemporary Omani society. 


\section{REFERENCES}

[1] Kechichian, J.A., Oman and the World: The Emergence of an Independent Foreign Policy, Rand: Santa Monica, CA, 1995.

[2] Al-Abdulsalam, S., Manah the state with a Long History, Customs and Traditions of the Arab Legacy, Muscat: Alnahda, 2002.

[3] Hakim, B.S., Arabic-Islamic Cities, Routledge, 2013.

[4] Benkari, N., The defensive vernacular settlements in Oman, a contextual study. International Journal of Heritage Architecture, 1(2), pp. 175-184, 2017.

[5] Dean, L., The Middle East and North Africa: Regional Surveys of the World, 50th ed., Europa: London, 2004.

[6] Ben-Hamouche, M., The changing morphology of the gulf cities in the age of globalization: The case of Bahrain. Habitat International, 28, pp. 521-540, 2004, www.elsevier.com/locate/habitatint

[7] Elsheshtawy, Y., Redrawing Boundaries: Dubai, an Emerging Global City. Planning Middle Eastern Cities: An Urban Kaleidoscope in a Globalizing World, Routledge: New York, pp. 169-199, 2004.

[8] Germeraad, P.W., Open Space in Human Settlements: The Lesson from the Islamic Tradition. Contemporary Design Considerations for Open Spaces in Arab-Muslim Human Settlements in the Middle East, Landbouwuniversiteit, 1990.

[9] Kiet, A., Arab culture and urban form. Faculty and Student Work, VII, pp. 36-45, 2010.

[10] Al Shueili, K.S.M., Towards a sustainable urban future in Oman: Problem \& process analysis: Muscat as a case study, Doctoral dissertation, Glasgow School of Art, 2015.

[11] Mokhtar, B., Marché foncier et espace social à Mascate, Oman. Cybergeo - European Journal of Geography, Online. Espace, société, territoire, Document 543, 2011.

[12] Abdelghani, M.I., The Impact of Shopping Malls on Traditional Retail Stores in Muscat. Case Study of Al-Seeb Wilayat. Regionalizing Oman, Vol. 6 of the United Nations University Series on Regionalism, Springer: Netherlands, pp. 227-247, 2013.

[13] Aljabri, H., The planning and urban design of liveable public open spaces in Oman: Case study of Muscat, Doctoral dissertation, Heriot-Watt University, 2014.

[14] Al-Awadhi, T., Monitoring and modeling urban expansion using GIS \& RS: Case study from Muscat, Oman. Urban Remote Sensing Joint Event - IEEE, pp. 1-5, 2007.

[15] Bamakhrama, S., Cities within cities: An urbanization approach in the gulf countries, Master of Arts in Architecture Thesis, University of California, 2015.

[16] http://www.nakheel.com; http://www.thepearlqatar.com/main.aspx

[17] Bagaeen, S., Brand Dubai: The instant city; or the instantly recognizable city. International Planning Studies, 12(2), pp. 173-197, 2007.

[18] Ewers, M.C. \& Malecki, E.J., Megaproject: A 4-Decade Perspective of the Gulf Development Model. Engineering Earth, Springer Netherlands, pp. 533-550, 2011.

[19] Katodrytis, G., The Dubai Experiment: Accelerated Urbanism, Dubai Guide: Al Manakh, pp. 38-46, 2008.

[20] Davis, M., Le Stade Dubaï du Capitalisme, Les Prairies Ordinaires, trans. by H. Jallon \& M. Saint-Upery, Paris, 2008.

[21] Reisz, T., Making Dubai: A process in crisis. Architectural Design, 80(5), pp. 38-43, 2010.

[22] Harris, R., Remote sensing of agriculture change in Oman. International Journal of Remote Sensing, 24(23), pp. 4835-4852, 2003. 
[23] Mokhtar, B., Urban Sprawl and City Vulnerability: Where Does Muscat Stand? Indian Ocean Tropical Cyclones and Climate Change, Springer Netherlands, pp. 233-243, 2010.

[24] El-Arifi, S., The nature of urbanization in the gulf countries. Geo Journal, 13(3), pp. 223-235, 1986. http://www.jstor.org/stable/41143721

[25] Yagoub, M., Monitoring of urban growth of a desert city through remote sensing: AlAin, UAE, between 1976 and 2000. International Journal of Remote Sensing, 25(6), pp. 1063-1076, 2004.

[26] Al-Belushi, M.A.K., The Heritage Prospective and Urban Expansions in Capital Cities: Old Defense Sites in Muscat-Oman. Structural studies, repairs and maintenance of Heritage architecture XIII, Wessex Institute of Technology press, pp. 556-563, 2013.

[27] Qiu, B., Thoughts on urbanization models from a global perspective. China Finance and Economic Review, 2(1), p. 1, 2014.

[28] Khan, M.A. \& Kumar, A., Impact of urban development on mangrove forests along the west coast of the Arabian Gulf. E-journal Earth Science India, 2, pp. 159-173, 2009.

[29] Benkari, N., The "sustainability" paradigm in architectural education in UAE contextual study. International Journal of Heritage Procedia - Social and Behavioral Sciences, 102, pp. 601-610, 2013.

[30] Ramadan, E., Sustainable urbanization in the Arabian Gulf region: Problems and challenges. Arts and Social Sciences Journal, 6, p. 109. DOI: 10.4172/2151-6200. 1000109 .

[31] Al-Rawas, G.A., Valeo, C., Khan, U.T. \& Al-Hafeedh, O.H., Effects of urban form on wadi flow frequency analysis in the wadi Aday watershed in Muscat, Oman. Urban Water Journal, 12(4), pp. 263-274, 2015.

[32] Kumar, A., Reclaimed islands and new offshore townships in the Arabian Gulf: Potential natural hazards. Current Science, 96(4), pp. 480-485, 2009.

[33] Wippel, S., Bromber, K. \& Krawietz, B. (eds), Under Construction: Logics of Urbanism in the Gulf Region, Routledge, 2016.

[34] Mokhtar, B., Is littoralization reconfiguring the Omani Territory? Regionalizing Oman, Springer Netherlands, pp. 217-225, 2013.

[35] Wippel, S., Regionalizing Oman: A new interest of research on Oman and its spatial dimensions. Regionalizing Oman, Springer Netherlands, pp. 1-18, 2013.

[36] Bonnenfant, P. (ed.), La Péninsule Arabique d'Aujourd'hui, Tome II: Etudes par Pays, Editions du CNRS: Paris, 1982.

[37] Lavergne, M. \& Dumortier, B. (eds), L'Oman Contemporain: Etat, Territoire, Identité, Karthala: Paris, 2002. 